\title{
Ticari Dışa Açıklığın Bölgesel İşsizlik Üzerindeki Etkisi: Türkiye Örneği ${ }^{1}$
}

\author{
Onur ERCAN*, Esin KILIÇ**
}

öz

Bölgesel işsizlik oranları, bölgesel gelişmişliğin emek piyasasına ilişkin temel göstergesi olarak ele alınmaktadır. Dolayısıyla, işsizlikle mücadele politikaları yatırımların bölgelere yayılmasını da sağlamalıdır. Ayrıca, dış ticaret daha geniş piyasalar için üretimi beraberinde getireceğinden; istihdam düzeyi, işletmelerin dış ticarete yönlendirilmesiyle de arttırılabilir. Bu nedenle, bölgesel düzeyde ticari dışa açıklık ile işsizlik arasındaki ilişkinin araştırılması önemlidir. Bu çalışmada Türkiye'de bölgesel ticari dışa açıklık ile işsizlik arasındaki ilişki, 2004-2014 dönemi için dinamik doğrusal panel veri analizi yöntemleri kullanılarak araştırılmıştır. Analiz sonuçları bölgesel ticari dışa açıklık endeksleri ile işsizlik oranı arasında negatif bir ilişki olduğunu işaret etmiştir. Ayrıca, Dumitrescu-Hurlin panel nedensellik testi sonuçları, bu iki değişken arasındaki ilişkinin çift yönlü olduğunu göstermiştir. Elde edilen sonuçlar, Türkiye'de bölgesel ticari dışa açıklığın arttırılmasına yönelik uygulanacak politikaların bölgesel işsizlik oranlarını azaltabileceği şeklinde yorumlanabilir.

Anahtar Kelimeler: Ticari Dışa Açılık, Bölgesel İşsizlik, Panel Veri Analizi

JEL Sınıflandırması: F16, R11, C33

\section{Impact of Foreign Trade Openness on Regional Unemployment: The Case of Turkey}

\begin{abstract}
Regional unemployment rates are the main indicator of regional development related to the labor market. Therefore, policies to combat unemployment should be ensured to spread the investments to the regions. Besides, since foreign trade will enable production for larger markets, the level of employment may be increased by directing enterprises to foreign trade. Consequently, it is important to investigate the relationship between foreign trade openness and unemployment at the regional level. In this study, the relationship between regional foreign trade openness and unemployment in Turkey were investigated using dynamic linear panel data analysis methods for period 2004-2014. Analysis results indicated a negative relationship between the regional foreign trade openness and the unemployment rate. In addition, the results of Dumitrescu-Hurlin panel causality test showed that the relationship between these two variables is bidirectional. According to these results, with the policies to increase regional trade openness, regional unemployment rate could be reduced in Turkey.
\end{abstract}

Keywords: Foreign Trade Openness, Regional Unemployment, Panel Data Analysis

JEL Classification: F16, R11, C33

Araştırma Makalesi - Geliş Tarihi / Received: 09.12.2018 Kabul Tarihi / Accepted: 18.12.2018

\footnotetext{
${ }^{1} \mathrm{Bu}$ çalışma Onur Ercan tarafından Dr. Öğr. Üyesi Esin Kılıç danışmanlığında Eskişehir Osmangazi Üniversitesi Sosyal Bilimler Enstitüsü’nde yürütülen “Türkiye'de Bölgesel Ticari Açıklı-İşsizlik İlişkisi: Düzey 2 Bölgeleri için Panel Veri Analizi” (2017) başlıklı yüksek lisans tezinden türetilmiştir.

* Doktora Öğrencisi, Eskişehir Osmangazi Üniversitesi, Sosyal Bilimler Enstitüsü, İktisat Anabilim Dalı, onurercan.9091@gmail.com, ORCID: 0000-0002-9187-6715

** Dr. Öğr. Üyesi, Eskişehir Osmangazi Üniversitesi, İktisadi ve İdari Bilimler Fakültesi, İktisat Bölümü, esinkilic@ogu.edu.tr, ORCID: 0000-0003-1681-5186
} 


\section{GİRIŞ}

Dünyada yaratılan toplam gelirden daha fazla pay alarak refah düzeyini arttırmak, ülkelerin temel makroekonomik amaçlarından biridir. Ancak, sahip oldukları üretim faktörü miktarı, teknoloji düzeyleri ve uyguladıkları ekonomi politikalarındaki farklılıklar, ülkelerin sosyo-ekonomik gelişmişlik düzeylerinin de farklı olmasına neden olmaktadır. Ülkelerin gelişmişlik düzeyleri arasındaki uçurumların azaltılması hatta ortadan kaldırılması, uluslararası kuruluşların odaklandığı en önemli sorunlardan biri haline gelmiştir.

Ülkeler ve makroekonomik politikaların uyumlaştırıldığı Avrupa Birliği gibi ekonomik birleşme hareketleri ise benzer bir sorunla bölgesel düzeyde mücadele etme çabası içerisindedir. Yatırımlar ve üretimin ülke ya da birlik içerisindeki belirli bölgelerde yoğunlaşmasının neden olduğu bölgesel refah farklılıkları, ancak bölgesel düzeyde erişilebilir olan ekonomik göstergeler incelendiğinde ortaya konulabilmektedir. Dolayısıyla temel ekonomik göstergelerin bölgesel olarak hesaplanması, elde edilen verilerin karşılaştırılması ve ülke ya da birlik refahından yeterince pay alamayan bölgelerin dezavantajlı durumunu ortadan kaldırmaya yönelik politikaların uygulanması önem arz etmektedir. Bu amaçla, Avrupa Birliği genelinde bölgesel istatistiklerin üretilmesi için bölgesel birimleri tanımlamak amacıyla Eurostat tarafindan The Nomenclature of Territorial Units for Statistics (NUTS) oluşturulmuş ve 2003 yılında NUTS sınıflandırması yasal bir çerçeveye oturtulmuştur. Türkiye de AB'ye uyum çalışmaları çerçevesinde, bölgesel istatistikleri hesaplamak amaciyla NUTS kriterlerine uygun şekilde İstatistiki Bölge Birimleri Sınıflamasına (IBBS) göre bölgesel birimleri belirlemiştir. İBBS'ye göre Türkiye için 1. düzeyde 12,2 . düzeyde 26 bölgesel birim tanımlanmış, 3 . düzey bölgeler olarak 81 il ele alınmış ve bu üç düzeydeki istatistiki bölge birimleri için istatistiki veriler hesaplanmaya başlanmıştır.

İstatistiki bölge birimleri özelinde hesaplanan ekonomik göstergelerden biri de bölgesel işsizlik oranlarıdır. Elhorst (2003), işsizliğin yalnızca makro düzeyde değerlendirilmemesi gerektiğini iki temele dayandırmaktadır. Bunlardan ilki, bölgesel işsizlik oranı farklılıklarının o ülkenin genel işsizlik oranına da yansıyacak olmasıdır. Bu açıdan, bölgesel işsizlik oranlarının düzenli olarak hesaplanmasıyla, hem bölgesel politikaların değerlendirilmesinde, hem de tümevarımsal bir yaklaşımla ülkeler arası gelişmişlik farklılıklarının belirlenmesinde kullanılabilecek önemli bir araç elde edilmiş olacaktır (Elhorst, 2003: 709). İkincisi ise bölgesel işsizlik oranları arasındaki farklılıklar ülke potansiyelinin altında ve verimsiz bir üretimin işareti olarak ele alınmakta, bu farklılıkların azaltılması veya ortadan kaldırılması durumunda artan milli gelirle, elde edilebilecek sosyal faydanın da artacağ 1 ifade edilmektedir (Elhorst, 2003: 710). Türkiye'deki istatistiki bölge birimleri için hesaplanan bölgesel işsizlik oranları, T.C. Kalkınma Bakanlığı (2013) tarafından yayınlanan sosyo-ekonomik gelişmişlik endeksi hesaplamalarında kullanılan istihdam göstergelerinden de biridir. Bu oranın yüksek olması ilgili istatistiki bölge biriminde etkin işlemeyen emek piyasasının varlığının bir göstergesi olarak ele alınmakta ve endeks değerini negatif etkilemektedir. Özetle, bölgesel işsizlik oranındaki farklılıklar, hem bölgesel hem de ülkeler arası gelişmişlik farklılıklarının oluşmasının sebeplerinden biri olarak ele alınmaktadır.

Ekonomik gelişmişlik seviyesinin düşük olmasının nedenlerinden biri olan yüksek ve sürekli işsizlik oranlarının bir taraftan bölge düzeyinde, diğer taraftan da bölgeler arasında azaltılması hatta ortadan kaldırılması gerekmektedir. Bu amaçla yatırımların arttırılmasının yanı sıra dezavantajlı bölgelere yayılması ve yönlendirilmesi önem arz etmektedir. Fakat dezavantajlı bölgelerdeki işletmelerin yalnızca bölgesel talebi karşılamaya yönelik üretim yapması bir çeşit kısır döngüye sebep olabilir. İşsizlik oranının daha yüksek, dolayısıyla da üretimin ve gelirin düşük olduğu bölgelerde bulunan ve yalnızca bu bölge pazarı için üretim yapan işletmeler, düşük bölge geliri nedeniyle düşük taleple karşlaşacaktır. Düşük bölgesel talep ise düşük üretim seviyeleri ve yüksek işsizlik oranlarının süreklilik arz etmesine sebep olacaktır. Dolayısıyla bu 
döngüyü kırmanın bir yolu, dezavantajlı bölgelerdeki işletmelerin bölgeler arası, ulusal düzeyde ve hatta uluslararası ticarete açık olmasıdır. İşletmelerin dış piyasalara yönelen ticari yapı kazanmasının, hedef pazarın genişlemesiyle üretimi ve dolayısıyla üretim faktörleri kullanımını artırıcı bir etki ortaya çıkarması muhtemeldir. Diğer taraftan yüksek kapasite kullanımı ve ölçek ekonomilerinin de etkisiyle üretim maliyetlerini düşürerek daha fazla kâr elde eden işletmeler, bölge gelirinin artmasını ve bölgede üretilen mallara yönelen iç talebin de genişlemesini sağlayabilir.

Bu çalışmada, Türkiye'de bölgesel dış ticarete açıklığın arttırılmasının bölgesel işsizlikle mücadelede etkili bir araç olup olmadığının araştırılması amaçlanmıştır. Bu amaç çerçevesinde, Türkiye'deki 26 istatistiki bölge biriminin (İBBS-düzey 2) 2004-2014 dönemi verileri kullanılarak panel veri analizi yöntemleri ile bölgesel ticari dışa açıklık ile işsizlik oranları arasında anlamlı bir ilişki bulunup bulunmadığı ortaya konulmaya çalışılmıştır.

\section{TICARİ DIŞA AÇIKLIK VE İŞSIZZLIKK İLIŞSISİ}

Dış ticaret ile faktör piyasaları arasındaki ilişkinin temelinde Faktör Donatımı Teorisi yatmaktadır. Faktör Donatımı Teorisi, yalnızca emek ve sermayenin üretim faktörü olarak ele alındığı bir durumda, her ülkenin bol olarak sahip olduğu üretim faktörünün yoğun şekilde kullanıldığı mallarda karşılaştırmalı üstünlüğe sahip olacağını ifade etmektedir. Bu bağlamda, dışa açık ve emek faktörü bakımından zengin bir ülkede ihracat, emek yoğun sektörler tarafından yapılacağı için, bu sektörlerdeki üretim artacaktır (Seyidoğlu, 2009: 86).

Faktör Donatımı Teorisi tam istihdam varsayımı altında oluşturulan bir teori olduğundan, bu teoriye dayanarak diş ticaretle artan üretimin, işsizliği azaltacağ şeklinde bir çıkarsama yapmak mümkün olmamakla birlikte, literatürde dış ticaret ile işsizlik oranı arasındaki olası ilişkiyi Faktör Donatımı Teorisi'ni temel alarak ortaya koyan çalışmalar bulunmaktadır. Bu çalışmalardan işsizliğin bir göstergesi olarak ekonometrik modele asgari ücret uygulamasını dâhil eden Brecher (1974), göreceli faktör zenginliğinin ticari liberalleşme ile refah ve işsizlik oranı arasındaki ilişkinin belirleyicisi olduğunu ortaya koymaktadır. Çalışmanın sonuçları, emek faktörünün bol olduğu (dolayısıyla emek yoğun malların ihraç edileceği) ülkelerde işsizlik oranının düşeceğini, sermaye faktörü bakımından zengin (emek yoğun malların ithal edileceği) ülkelerde ise işsizlik oranının artacağını göstermektedir. Davidson, Martin ve Matusz (1999) da, Brecher'in (1974) sonucunu destekler şekilde dış ticaret ile işsizlik oranı arasındaki ilişkinin göreceli faktör donatımına bağlı olduğunu ileri sürmüşlerdir. Davis (1998), Brecher'in (1974) modelinden yola çıkarak ücret düzeyinin esnek olduğu $\mathrm{ABD}$ ve asgari ücret uygulamasının bulunduğu İngiltere'nin, otarşik yapıyı terk ederek birbirleriyle serbest ticarete başlamaları durumunda iki ülkenin emek piyasasındaki değişmelerini araştırmıştır. Çalışma sonuçlarına göre, serbest ticarete geçiş ile asgari ücretin uygulandığ 1 İngiltere'de işsizlik iki katına çıkmıştır. Davis $(1998,483)$ bu sonucu, ülkelerinde işsizlik sorunu bulunmamasına rağmen İngiltere'deki yüksek ücretlerden yararlanmak isteyen Amerikalıların İngiltere'ye göç etmelerine dayandırmaktadır. Faktör Donatımı Teorisi'nin teorik varsayımına uygun şekilde ülkeler arası emek hareketlerinin bulunmadığı durumda ise İngiltere aynı ücret düzeyinde daha düşük bir işsizlik oranı elde edebilecektir. Dutt, Mitra ve Ranjan (2008) ise 92 ülkenin 1990-2000 dönemi verileriyle dış ticarete açıklık ile işsizlik arasındaki ilişkiyi Ricardo modeli ve Faktör Donatımı Teorisi çerçevesinde incelemiştir. Çalışmada elde edilen bulgular, incelenen ülkelerin göreceli faktör donatımından bağımsız bir şekilde, korumacı hükümet müdahalelerini temsil etmek üzere modele dâhil edilen farklı değişkenlerin işsizlik oranını arttırdığını, dış ticarete açıklığın ise işsizliği azaltıcı bir etkisi olduğunu göstermektedir.

Ticari dışa açıklığın işsizlik üzerine etkisini Faktör Donatımı Teorisi çerçevesinde ele alan çalışmalarda, genellikle emek zengini ülkelerde daha fazla ticari dışa açıklığın işsizlik 
oranını azaltabileceği sonucu elde edilmiştir. Ortak özelliklerinden biri yüksek nüfus ve nüfus artış oranı olan ve bu nedenle de görece emek zengini olarak değerlendirilebilecek az gelişmiş ve gelişmekte olan ülkeler için yapılan çalışmaların bulgularıyla da bu sonuç desteklenebilmektedir. Papageorgiou, Choksi ve Michaely (1990), gelişmekte olan 9 ülkede yapılan ticari reformların istihdam üzerindeki etkilerini araştırmıştır. İncelenen ülkelerden sekizinde liberal politikaların benimsendiği dönemdeki işsizlik oranının, bu politikalara geçişten önceki yıla göre daha az olduğunu tespit etmiştir. Gelişmekte olan ülkeleri inceleyen bir diğer çalışma olan Rama (2003), küreselleşmenin ortaya çıkardığı finansal şokların, bu ülkelerde geçici işsizlik şokları oluşturduğunu belirtmektedir. Ancak küreselleşmenin neden olduğu bu geçici işsizlik artışları göz ardı edildiğinde, ticaret yoğunluk oranının yüksek olduğu ülkelerde görece daha düşük işsizlik oranlarının gözleneceği belirtilmektedir. Kılıç ve Kutlu (2017), 17 geçiş ekonomisi için 1998-2014 dönemi verileriyle ticari dışa açıklığın işsizlik oranı üzerine uzun dönemli etkisini araştırmışlardır. Çalışma bulgularına göre, geçiş ekonomilerinde ticari dışa açıklıktaki artış işsizlik oranını azaltmaktadır. Fu ve Balasubramanyam (2005: 622-623), 1987-1998 döneminde Çin'in 29 bölgesinin ihracatı ile bu bölgelerdeki emek talebi arasındaki ilişkiyi araştırmıştır. Elde edilen sonuçlara göre ihracattaki artış bu bölgelerdeki istihdamı da arttırmaktadır. Sektörel düzeyde bir çalışma olan Nicita (2006) ise Madagaskar'daki tekstil ve hazır giyim endüstrisini temel alarak ihracat ile yoksulluk arasındaki ilişkiyi değerlendirmiş ve ihracatın yoksulluğu azalttığı sonucuna ulaşmıştır. Bu etki ihracatın istihdam yaratması ve ücret düzeyini arttırması ile oluşmaktadır. Ayrıca istihdam yaratma etkisi hem vasıfsız hem de vasıflı işçiler üzerinden ortaya çıkmaktadır (Nicita, 2006: 22).

Literatürde dış ticarete açıklık ile işsizlik oranı arasındaki ilişki, yalnızca Faktör Donatımı Teorisi çerçevesinde incelenmemektedir. Örneğin Felbermayr, Prat ve Schmerer (2008), heterojen firmaların bulunduğu bir piyasada ticari liberalleşme ile işsizlik arasındaki ilişkiyi araştırırken, çalışmalarına iş arama modeli yaklaşımını da dâhil etmişlerdir. Çalışma sonucunda elde edilen temel sonuç ise dış ticarete açılmanın işsizlik oranını azaltacağıdır (Felbermayr vd., 2008: 33-34). Aslında literatürde, gelişmiş ve dolayısıyla Faktör Donatımı Teorisi çerçevesinde görece sermaye zengini olarak değerlendirilebilecek ülkeler üzerine yapılan ampirik çalışmalar da, Dutt vd.'nin (2008) bulgusunu destekleyecek şekilde, diş ticarete açıklığın işsizliği azaltıcı etkisinin yalnızca emek zengini ülkelerde ortaya çıkmadığını işaret etmektedir. Bu çalışmalardan Felbermayr, Prat ve Schmerer (2009: 21-22), 20 OECD ülkesi için 1980-2000 dönemi verileri ile ticari dişa açıklık ile işsizlik ilişkisini panel veri analizi yöntemi kullanarak araştırmış ve bu iki değişken arasında negatif bir ilişki olduğunu saptamışlardır. Çalışmada elde edilen sonuçlara göre toplam dış ticarete açıklık \%10 oranında arttığında, toplam işsizlik oranı \%1 oranında azalmaktadır. Gozgor (2014, 1032-1033), G7 ülkelerinde ticari dışa açıklık ile işsizlik arasındaki ilişkiyi dört farklı ticari dışa açıklık ölçütü kullanarak panel veri analiziyle incelemiş ve bu ülkelerde ticari dışa açıklığın işsizliği azalttığı sonucuna ulaşmıştır. Yılmaz ve Altay (2016) ise 1990-2014 dönemi verileriyle G8 ülkelerindeki dış ticarete açılılı ile işsizlik ilişkisini panel veri analizi yaklaşımıyla incelemişlerdir. Bu çalışmanın sonuçlarına göre dış ticarete açıklığın artması Almanya, Japonya ve Kanada'da işsizlik oranını azaltırken, ABD, Fransa, İngiltere, İtalya ve Rusya için dışa açıklık ölçütü olarak ele alınan ticaret yoğunluk oranı ile işsizlik arasında istatistiksel olarak anlamlı bir ilişkiye ulaşılamamıştır (Yılmaz ve Altay, 2016: 841).

Literatürdeki teorik ve ampirik çalışmaların önemli bir kısmı dış ticarete açıklığın işsizliği azaltıcı etkisini işaret etmekle birlikte, özellikle son dönem çalışmalara bakıldığında dış ticarete açıklık ile işsizlik arasında bir ilişki bulunmayabileceği ya da aralarındaki ilişkinin yönünün pozitif olabileceği de ifade edilmektedir. Bu çalışmalardan Moore ve Ranjan (2005: 414), dişa açıklığın toplam işsizlik üzerindeki etkisinin belirsizliğine dikkat çekmektedir. Çalışmanın sonuçlarına göre, ülkedeki işgücünü ağırlıklı olarak nitelikli işçiler oluşturuyorsa, dışa açılma o ülkedeki toplam işsizliği azaltırken, işgücü içerisinde vasıfsız işçilerin fazla olduğu 
ülkelerde ise işsizliği arttıracaktır. De Pinto (2013: 28-29), dışa açıklık ile işsizlik ilişkisini, işçilerin ve firmaların heterojen olduğu kabul edilen Melitz'in (2003) çalışmasını temel alarak incelemiştir. Bu çerçevede dış piyasalardaki rekabet gücünü arttırmak isteyen firmaların nitelikli işgücü çalıştırmayı tercih edecekleri değerlendirilmektedir. Dolayısıyla niteliksiz işgücünün uzun süreli işsizlik problemi ile karşı karşıya kalacağı, işgücün büyük bir kısmının niteliksiz ya da düşük nitelikli işçilerden oluştuğu durumda ise serbest ticarete geçişle birlikte ülkedeki işsizlik oranının da artacağı belirtilmektedir. Helpman, Itskhoki ve Redding (2011: 31), dış ticaret ile ücret eşitsizliği ve işsizlik arasındaki ilişkiyi araştırdığı çalışmalarında, liberal dış ticaret politikalarına geçişin bir taraftan ülkedeki refah düzeyini arttırırken, diğer taraftan da ülkedeki ücret eşitsizliğini ve işsizlik oranını yükselttiğini ifade etmektedir. Kamei (2014), serbest ticarete geçişin oluşturacağı rekabet ortamının işsizlik oranları üzerindeki etkisini, Neary'in (2009) genel oligopolistik denge modeline Shapiro ve Stiglitz'in (1984) verimlilik ücreti modelini dâhil ederek araştırmıştır. Çalışma sonuçlarına göre, serbest ticarete geçişle birlikte fiili ücretler artmakta, fiili ücretlerdeki artış ise işsizlik oranını arttırmaktadır (Kamei, 2014: 2). Fugazza, Carrère, Olarreaga ve Robert-Nicoud (2014) ise 97 ülke için ticari dişa açıklı̆̆ı işsizliğe etkisini 1995-2009 dönemi verilerini kullanarak panel veri analiziyle incelemişlerdir. Dış ticaret ile işsizlik arasındaki ilişkiyi gözlemlemek amacıyla karşıllaştırmalı üstünlük ile sektör düzeyinde işgücü piyasası sürtüşmeleri arasındaki kovaryansın değerlendirildiği çalışmada, kovaryans değeri negatifken dış ticaretin işsizlik oranını azaltacağı, pozitif değere sahip olduğunda ise daha fazla dışa açıklığın işsizlik oranını da arttıracağı ifade edilmektedir (Fugazza vd., 2014: 23).

\section{TÜRKIYE'DE TICCARI DIŞA AÇIKLIĞIN ISŞSIZLIIK ÜZERINE ETKILLERİ}

1980'li y1llarda başta gümrük tarifesi indirimleri olmak üzere ticari engellerin büyük ölçüde azaltılmasının ardından, 1995'te Dünya Ticaret Örgütü'nün kuruluşu ve üye sayısının her geçen gün artması ve 1996 yılında Avrupa Birliği ile Gümrük Birliği’nin yürürlüğe girmesinin de etkisiyle, Türkiye her geçen gün daha dişa açık bir görünüm sergilemektedir. Türkiye'de uygulanan dişa açık politikaların makroekonomik göstergeler üzerindeki etkileri ise pek çok çalışmanın konusu olmuştur. Bu çerçevede, Türkiye'nin ticari dışa açıklığının işsizlik üzerindeki etkileri uygulamalı analizlerle de ortaya konulmaya çalışılmıştır.

Erlat (2000), Türkiye'deki ihracat ve ithalat hacminin istihdam üzerindeki etkisini, Ankara Anlaşması'nın imzalandığı tarihten başlayan oldukça kapsamlı bir dönemi 4 alt döneme ayırarak incelemiştir. Çalışmanın sonuçları, 1980 yılı sonrasında uygulanan dişa açık politikaların istihdamı arttırıcı etkisinin yalnızca kısa dönemde ortaya çıktığını işaret etmektedir. Polat ve Uslu (2010), 1988-2007 dönemine ait 3 aylık verilerle dış ticaret ile istihdam arasındaki ilişkiyi gecikmesi dağıtılmış otoregresif modeller yardımı ile test etmiştir. Elde edilen sonuçlar, kısa vadede dış ticaretin istihdamı arttırıcı etkisinin uzun dönemde anlamını yitirdiği şeklindedir. Gül ve Kamacı (2012), dış ticaretin işsizliğe etkilerini, aralarında Türkiye'nin de bulunduğu 7 gelişmekte olan ülkenin 1993-2010 ve 12 gelişmiş ülkenin 1980-2010 verilerini kullanarak araştırmıştır. Çalışmada, gelişmiş ve gelişmekte olan ülkelerde ithalat ve ihracattan işsizliğe doğru tek yönlü bir nedensellik ilişkisi olduğu tespit edilmiştir. Sandalcılar ve Yalman (2012) ise Türkiye'de 1980-2010 yılları arasındaki 30 yıllık periyotta ticari serbestlik ile istihdam arasındaki ilişkiyi araştırmıştır. Çalışmada yürütülen eşbütünleşme testinin sonuçları ticari serbestlik ile istihdam arasında kısa dönemde anlamlı bir ilişki olmadığını göstermiştir. Granger nedensellik testi ve Hsiao testi sonuçlarına göre ise ticari serbestlikten istihdama doğru negatif bir nedensellik ilişkisi bulunmaktadır.

Görece daha yakın geçmişe odaklanan çalışmalardan Polat, Uslu ve Aydemir (2011), Türkiye için 2003-2008 dönemi dış ticareti ile istihdam düzeyi arasındaki ilişkiyi ele almaktadır. Panel veri analizi sonuçlarına göre dış ticaret ile istihdam arasında anlamlı bir ilişki 
bulunamamıştır. Özel, Topkaya ve Kurt (2012), Türkiye'de 2005-2011 dönemindeki ticari dışa açıklığın işsizlik üzerindeki uzun dönemli etkisini eşbütünleşme testi, kısa dönemli etkisini ise VAR analizi ve Granger nedensellik testleriyle araştırmışlardır. Analiz sonuçlarına göre kısa dönemde ticari dışa açıklık ile işsizlik arasında çift yönlü nedensellik ilişkisi bulunmakla birlikte, bu iki değişken arasında uzun dönemde anlamlı bir ilişki tespit edilememiştir.

Ayaş ve Çeştepe (2010), Türkiye'de 1998-2002 yılları arasında gerçekleşen dış ticaret değişmelerinin istihdam ile ilişkisini sektörel bazda incelemiştir. Çalışma bulguları, dış ticaretteki değişmelerin istihdam üzerindeki etkisinin sektörden sektöre farklılaştı̆̆ 1 , diş ticaret değişiminin en fazla istihdam artışı sağladığı sektörlerin ise kauçuk ve plastik sektörleri olduğu şeklindedir. Dış ticarete açıklık ile işsizlik arasındaki ilişkiyi bölgesel düzeyde inceleyen Gozgor ve Piskin (2011), ise analizini 26 istatistiki bölge biriminin 2004-2009 dönemi yıllık verileri ile yürütmüştür. Ticarete açıklık ölçütü olarak bölge dış ticaretinin Türkiye'deki toplam dış ticaret içindeki payının kullanıldığı analiz sonuçları, dış ticarete açıklıkla işsizlik arasında negatif yönlü bir ilişki bulunduğunu göstermiştir.

Bölgesel düzeyde dış ticarete açıklık ile işsizlik arasındaki ilişkinin araştırıldığı bu çalışma ise gerek kapsadığı dönem, gerekse kullanılan dış ticarete açıklık ölçütü açısından Gozgor ve Piskin'in (2011) çalışmasından farklılaşmaktadır.

\section{VERI SETI}

Bu çalışmada Türkiye'deki ticari dışa açıklık ile işsizlik arasındaki ilişki, İBBS-Düzey 2 çerçevesinde belirlenmiş olan 26 istatistiki bölge birimi için 2004-2014 yıllık verileri ile incelenmektedir. 26 istatistiki bölge biriminin işsizlik oranı verileri ile dış ticarete açıklık endekslerini hesaplamakta kullanılacak bölgesel bazda gayrisafi yurtiçi hâsıla (GSYH), ihracat ve ithalat verileri Türkiye İstatistik Kurumu (TÜIK) veri tabanından sağlanmıştır. TÜİK veri tabanında bölgesel ihracat ve ithalat verileri dolar, GSYH değerleri ise TL cinsinden sunulmakta olduğundan, TL cinsinden elde edilen bölgesel GSYH değerleri, Türkiye Cumhuriyet Merkez Bankası (TCMB) Elektronik Veri Dağıtım Sistemi (EVDS) üzerinden sunulan dolar/TL efektif satış kuru yıllık ortalamasına bölünerek dolar cinsinden bölgesel GSYH değerlerine ulaşılmıştır.

Nominal dış ticarete açılık oranı ((ihracat+ithalat)/nominal GSYH), literatürde sıklıkla ticari dışa açıklık ölçütü olarak kullanılmakla birlikte, dış ticarete açıklığı doğru yansıtamayabileceği noktasında da eleştirilmektedir. Bölgesel düzeyde sunulan başka bir dış ticarete açıklık ölçütüne ulaşılamadığ iç̧in, ikinci bir ölçüt olarak Alcalâ ve Ciccone (2004) tarafından önerilen reel dış ticarete açıklık endeksi ((ihracat+ithalat)/reel GSYH) hesaplanmıştır. Reel diş ticarete açıklık endeksini hesaplarken kullanılacak bölgesel reel GSYH değerleri, TL cinsinden nominal değerlerin TCMB EVDS'den temin edilen bölgesel tüketici fiyat endeksi (TÜFE) değerlerine bölünmesiyle elde edilmiş ve yukarıda bahsedildiği şekilde dolar cinsinden değerlere çevrilmiştir. Modelde kullanılan bir diğer değişken olan ekonomik büyüme değişkenine ilişkin veriler de bölgesel reel GSYH'deki yıllık yüzde artışlar şeklinde hesaplanmıştır.

Bölgesel dış ticarete açılı̆ğın bölgesel işsizlik oranları üzerinde anlamlı bir etkisi olup olmadığını araştırmak amacıyla kurulan modele, ekonomik teoride işsizlikle ilişkilendirilen kontrol değişkenleri eklenmiştir. Bu kontrol değişkenlerinden ilki olan reel GSYH'deki artış, Okun yasası çerçevesinde işsizlikle ilişkilendirilmekte ve iç piyasadaki genişlemeyi temsil etmek amacıyla modele dâhil edilmektedir. Ancak işsizlik oranı ile reel GSYH'yi doğrudan ilişkilendiren uygulamalı çalışmalar da göz önünde bulundurularak, kontrol modellerine ekonomik büyüme değişkeni yerine reel GSYH değişkeni eklenmiştir. Enflasyon oranı ise ekonomik teoride Phillips eğrisi üzerinden işsizlik oranı ile ilişkilendirilen bir değişkendir ve 
ikinci bir kontrol değişkeni olarak modelde yer almaktadır. Enflasyon oranı değişkenine ait veriler, bölgesel TÜFE değerlerindeki yüzde artışlar şeklinde elde edilmiştir.

TÜIKK'in bölgesel GSYH'ye ilişkin veri sağladığı son yılın 2014 yılı olması nedeniyle analiz dönemi uzatılamamıştır. Bölgesel verilerin derlenerek sunulmaya başlandığ 1 ilk yıl olan 2004 ise, analiz döneminin başlangıç yılıdır. Çalışmada 26 yatay kesitin (istatistiki bölge birimi) ve her bir yatay kesit için 11 zaman boyutunun olduğu, toplamda 286 gözlem değeri içeren bir panel veri seti ile çalışılmıştır. Tablo 1'de veri setinin betimsel istatistikleri sunulmaktadır.

Tablo 1: Betimsel İstatistikler

\begin{tabular}{lccccc}
\hline Değişken & Ortalama & Standart Hata & Maksimum & Minimum & Gözlem Sayısı \\
\hline UNEMP & 10.16434 & 3.905155 & 24 & 1.8 & 286 \\
NTOI & 19.16096 & 18.76838 & 80.784 & 0.902577 & 286 \\
RTOI & 33.15791 & 34.92992 & 190.3083 & 1.052419 & 286 \\
GROWTH & 4.47587 & 4.768062 & 17.31356 & -9.04881 & 260 \\
LNRGDP & 16.60467 & 0.842143 & 19.34307 & 15.0875 & 286 \\
$\boldsymbol{I N F}$ & 8.452852 & 1.433369 & 12.7839 & 4.175323 & 260 \\
\hline
\end{tabular}

Tablo 1 incelendiğinde, 26 istatistiki bölge biriminin 2004-2014 dönemi ortalama işsizlik oranının $(U N E M P) \% 10$ düzeyinde olduğu görülmektedir. Nominal dış ticarete açıklık endeksinin (NTOI) dönem ortalama değerinden, bölgelerin ticaret hacminin, nominal GSYH'lerinin ortalama \%19'u kadar olduğu çıkarsaması yapılabilir. Oldukça düşük olan bu ortalama değerin ise bölgesel bazdaki değerlerden oldukça farklılaştığı, dolayısıyla bölgelerin nominal diş ticarete açıklıkları arasında oldukça önemli bir fark olduğu, bu değişken için elde edilen standart hata değeri incelendiğinde görülebilecektir. Tablo 1'e göre benzer bir durum reel ticari açıklık endeksi (RTOI) için de geçerlidir. Bölgelerin ortalama RTOI değerleri yaklaşık olarak \%33'tür. Bölgeler için ortalama dış ticari açıklık bu endeks ile daha yüksek hesaplanmış olmakla birlikte, bu değişken için hesaplanan yüksek standart hata değerleri de yüksek bölgeler arası dış ticarete açıklık farklılıklarını göstermektedir.

Kontrol değişkeni olarak modele dâhil edilen bölgelerin ekonomik büyüme oranı (GROWTH), ilgili dönemde ortalama \%4.5 olarak gerçekleşmiştir ve bu değişken için elde edilen standart hata değeri, bölgelerin büyüme performanslarında farklllıklar olduğunu işaret etmektedir. Logaritmik formda modele dâhil edilen reel GSYH'nin (LNRGDP) dönem ortalaması ise 16.6'dır. Modeldeki ikinci kontrol değişken olan enflasyon oranının (INF) ortalama değeri ise ilgili dönem için \%8.45 olarak hesaplanmıştır.

\section{MODEL VE YÖNTEM}

Bölgesel dış ticarete açıklık ile işsizlik arasındaki ilişkinin panel veri analizi yöntemleri kullanılarak araştırıldığı bu çalışmada, araştırmaya temel oluşturacak genel model Eşitlik 1'de verilmiştir.

$$
\begin{gathered}
U N E M P_{i t}=\alpha_{0}+\sum_{i=1}^{n} \alpha_{n} U N E M P_{i, t-n}+\beta_{1} \text { TOI I }_{i, t}+\beta_{2} G R O W T H_{i, t}+\beta_{3} I N F_{i, t}+\varepsilon_{i, t} \\
i=1, \ldots, 26, \quad t=2004, \ldots, 2014
\end{gathered}
$$

Eşitlik 1'deki modelde $i$ alt indisi, gözlemin hangi istatistiki bölge birimine ait olduğunu, $t$ alt indisi ise gözlem yılını göstermektedir. Bölgesel işsizliğin, kendi geçmiş dönem değerleri 
ile ilişkisini inceleyebilmek amacıyla işsizlik oranının gecikmeli değerleri de modele eklenmektedir. Eşitlik 1'de verilen modelde TOI ile gösterilen dış ticarete açıklık değişkeni olarak nominal dış ticarete açıklık endeksi (NTOI) ve reel dış ticarete açıklık endeksi (RTOI) şeklinde iki farklı değişken kullanılmasıyla, dış ticarete açıklık ile işsizlik oranı arasındaki ilişki farklılaştırılmış modeller üzerinden analiz edilmiştir. Ayrıca Eşitlik 1'de yer alan ekonomik büyüme (GROWTH) değişkeninin yerine modelde logaritmik formdaki reel GSYH (LNRGDP) değişkeni kullanılarak modelin sağlamlık kontrolü de yapılmıştır.

Konjonktür teorilerine göre, makroekonomik değişkenlerin herhangi bir zaman diliminde karşı karşıya kaldığ 1 şokların etkisi gelecek dönemlerde de kendisini gösterebilmektedir. Böyle bir durumun varlığı ise bağımlı değişkenin kendi gecikmeli değerlerinin modele dâhil edilmesiyle ortaya konulabilmektedir. Belirli bir dönemde ortaya çıkan bir şokun kalıcılı̆̆ı, makroekonomik değişkenlerin gecikmeli değerleri ile aynı yönde değiştiğinin işareti olan bağımsız değişkenin gecikmeli değerlerinin pozitif katsayı alması şeklinde gözlenmektedir. $\mathrm{Bu}$ nedenle Eşitlik 1'deki modelde yer alan $\alpha_{1}, \alpha_{2}, \ldots, \alpha_{n}$ katsayılarının, işsizlik oranları üzerinde kalıcı bir şokun varlığı durumunda pozitif elde edilmesi beklenmektedir. İşsizlik oranının kaç döneme kadar gecikmeli değerleriyle modele dâhil edileceğini ise analiz sonucu elde edilen katsayıların anlamlılı̆g 1 belirleyecektir.

Kontrol değişkenleri için katsayı beklentileri ekonomik teoriye dayanarak oluşturulmuştur. Ekonomik teoride Okun yasasıyla ekonomik büyüme ile işsizlik oranı arasında ters yönlü bir ilişki olacağı belirtildiğinden, Eşitlik 1'deki $\beta_{2}$ katsayısının negatif olması beklenmektedir. Enflasyon ile işsizlik arasındaki negatif yönlü değiş tokuşu grafiksel olarak gösteren Phillips eğrisi çerçevesinde $\beta_{3}$ katsayısı ile ilgili beklenti de negatif elde edileceği yönündedir.

Çalışmada dış ticarete açıklık değişkenine ait $\beta_{1}$ katsayısının alacağı işaret ve bu katsayının istatistiksel olarak anlamlı olup olmaması, bölgesel işsizlikle mücadelede dış ticarete açıklığın bir araç olarak kullanılıp kullanılamayacağına ilişkin yorumların yapılmasında kullanılacak temel bilgiyi sağlayacaktır.

Tablo 2'de, Eşitlik 1'de verilen modelin tahmininde çoklu doğrusal bağlantı sorunu ile karşılaşmamak için incelenen ikili korelasyon matrisi sunulmaktadır.

Tablo 2: İkili Korelasyon Matrisi

\begin{tabular}{lcccccc}
\hline & UNEMP & GROWTH & LNRGDP & INF & NTOI & RTOI \\
\hline UNEMP & 1.000 & & & & & \\
GROWTH & -0.109 & 1.000 & & & & \\
LNRGDP & 0.203 & 0.054 & 1.000 & & & \\
INF & -0.052 & -0.047 & -0.015 & 1.000 & & \\
NTOI & 0.240 & 0.109 & 0.669 & -0.016 & 1.000 & 1.000 \\
RTOI & 0.184 & 0.126 & 0.660 & -0.053 & 0.947 & \\
\hline
\end{tabular}

Tablo 2 incelendiğinde, UNEMP ile modelde yer alacak bağımsız değişkenlerin ikili korelasyon katsayılarının oldukça düşük değerler aldığı görülmektedir. LNRGDP ile ticari dışa açıklık değişkenleri olan NTOI ve RTOI değişkenlerinin ikili korelasyon katsayıları görece yüksek elde edilmekle birlikte, bu katsayıların çoklu doğrusal bağlantı sorunu ortaya çıkaracak ölçüde yüksek olmadıkları şeklinde bir değerlendirme yapılabilir. NTOI ve RTOI değişkenlerinin ikili korelasyon katsayıları ise değişkenler arasında güçlü bir ilişki olduğunu göstermektedir $(\mathrm{r}=0.947)$. NTOI ve RTOI, bölgesel diş ticarete açıklığı temsil etmekte 
kullanılacak alternatif göstergeler oldukları ve modele birlikte dâhil edilmeyecekleri için, tahmin edilecek modellerde çoklu bağlantı sorunu ile karşılaşılmayacağını söylemek mümkündür.

26 istatistiki bölge birimi ve her birim için elde edilen 11 zaman boyutuna sahip panel veri seti tahminlenirken hangi panel veri analiz yönteminin daha uygun olduğunu belirleyebilmek amacıyla, ilk önce veri setindeki her bir değişkene panel birim kök testi uygulanarak birim köke sahip olup olmadıklarının belirlenmesi gerekmektedir. Panel birim kök test sürecine geçmeden önce ise dengeli ve dengesiz panel veri setleri için gözlem ve zaman boyutları görece sinırlı olduğunda bile uygulanabilen Pesaran yatay kesit bağımlılığı testi uygulanmıştır (Pesaran, 2004: 23). Ardından Pesaran yatay kesit bağımlılık testinden elde edilen sonuçlar da değerlendirme sürecinde kullanılmak üzere, yatay kesit bağımlılı̆̆ını göz önünde bulundurmayan birinci nesil panel birim kök testlerinden Maddala ve Wu (1999) ve yatay kesit bağımlılığını dikkate alan ikinci nesil panel birim kök testlerinden Pesaran (2007) uygulanarak değişkenlere ait verilerin birim köke sahip olup olmadıkları sınanmıştır. Ekonometrik tahminleme sürecinde bağımlı değişkenin kendi gecikmeli değerleri ile ilişkili olması durumunda, tahminleme yapılırken dinamik modeller kullanılması gerektiğinden, dinamik doğrusal tahminleme yöntemlerinden Arellano-Bond ve Arellano-Bover/Blundell-Bond tahminleme yöntemleri kullanılmıştır. Ayrıca değişkenler arasındaki ilişkinin varlığ 1 ve bir ilişki varsa bu ilişkinin yönü Dumitrescu ve Hurlin (2012) panel Granger nedensellik testi yardımı ile de araştırılmıştır.

\section{EKONOMETRİK ANALIZZ}

Türkiye'de bölgesel dış ticarete açıklığın işsizlik üzerindeki etkilerini araştırmak amaciyla yürütülecek ekonometrik analiz süreci öncesinde, panel veri setinde yatay kesit bağımlılığı olup olmadığını sınamak için Pesaran (2004) yatay kesit bağımlılığı testi uygulanmıştır. Sıfır hipotezinin yatay kesit bağımlılı̆̆ının yokluğunu ifade ettiği Pesaran (2004) yatay kesit bağımlılığ test sonuçları Tablo 3’te verilmiştir.

Tablo 3: Pesaran Yatay Kesit Bağımlılığı Test Sonuçları

\begin{tabular}{lcccc}
\hline & $\begin{array}{c}\text { CD-Test } \\
\text { İstatistiği }\end{array}$ & $\begin{array}{c}\text { p Olasılık } \\
\text { Değeri }\end{array}$ & $\begin{array}{c}\text { Ortalama Korelasyon } \\
\text { Katsayısı }\end{array}$ & $\begin{array}{c}\text { Ortalama Mutlak } \\
\text { Korelasyon Katsayısı }\end{array}$ \\
\hline UNEMP & 17.78 & 0.000 & 0.297 & 0.427 \\
GROWTH & 42.74 & 0.000 & 0.750 & 0.751 \\
LNRGDP & 58.54 & 0.000 & 0.979 & 0.979 \\
INF & 38.94 & 0.000 & 0.683 & 0.687 \\
NTOI & 20.32 & 0.000 & 0.340 & 0.520 \\
RTOI & 51.98 & 0.000 & 0.869 & 0.869 \\
\hline
\end{tabular}

Tablo 3'te sunulan yatay kesit bağımlılığı (CD) test istatistikleri ve bu istatistiklere ait olasılık değerleri (p), panel veri setinde yer alan tüm değişkenler için sıfır hipotezinin reddedildiğini ve dolayısıyla her bir değişken için yatay kesitler arasında bağımlılığın bulunduğunu işaret etmektedir. Bu nedenle bir sonraki aşamada yatay kesit bağımlılığını göz önünde bulunduran ve bulundurmayan farklı birim kök testleri kullanılarak birim kök sinaması yapılacak, ancak test sonuçların farklılaşması durumunda yatay kesit bağımlılığını göz önünde bulunduran ikinci nesil birim kök testinin sonuçları dikkate alınacaktır. Birim kök sınaması yapılırken birinci nesil panel birim kök testlerinden Maddala ve Wu (1999) ve ikinci nesil panel birim kök testlerinden Pesaran (2007) testi uygulanmıştır. Her iki panel birim kök testi için de sıfır hipotezi, sınamanın yapıldığı değişkene ilişkin veri setinin birim kök içerdiği; diğer bir 
deyişle değişkenin durağan bir seyir izlemediği şeklindedir. Her iki panel birim kök sınaması da modele yalnızca sabitin eklendiği ve sabitle birlikte trendin de modelde yer aldığı alternatif modeller üzerinden yürütülmüş ve elde edilen sonuçlar Tablo 4'te verilmiştir.

Tablo 4: Panel Birim Kök Test Sonuçları

\begin{tabular}{|c|c|c|c|c|}
\hline & \multicolumn{2}{|c|}{ Birinci Nesil: Maddala ve Wu $\left(\chi^{2}\right)$} & \multicolumn{2}{|c|}{ İkinci Nesil: CIPS (z( $(\bar{t}))$} \\
\hline & Sabitli & Sabitli ve Trendli & Sabitli & Sabitli ve Trendli \\
\hline UNEMP & $144.218 * * *$ & $142.635^{* * *}$ & $-2.709 * * *$ & $-2.127 * *$ \\
\hline GROWTH & $158.648 * * *$ & $83.737 * * *$ & $-7.259 * * *$ & $-3.596^{* * *}$ \\
\hline$L N R G D P$ & 6.531 & 24.310 & $-2.020 * *$ & $-4.382 * * *$ \\
\hline$I N F$ & $372.801 * * *$ & $344.140 * * *$ & $-5.453 * * *$ & $-1.847 * *$ \\
\hline NTOI & 44.294 & $70.477 * *$ & $-2.375 * * *$ & -0.934 \\
\hline RTOI & 10.248 & $70.825 * *$ & $-2.707 * * *$ & -0.401 \\
\hline$\triangle N T O I$ & $274.793 * * *$ & $183.133^{* * *}$ & $-7.198 * * *$ & $-4.493 * * *$ \\
\hline$\triangle R T O I$ & $239.154 * * *$ & $153.059 * * *$ & $-6.462 * * *$ & $-4.324 * * *$ \\
\hline
\end{tabular}

*: \%10, **: \%5, ***: \%1 anlam düzeyinde anlamlılığı göstermektedir. Gecikme uzunlukları belirlenirken Akaike Enformasyon Kriteri (AIC) kullanılmıştır.

Değişkenlerin durağanlığını sınamak amacıyla yapılan Maddala ve Wu (1999) birim kök testi sonuçlarına göre $U N E M P, G R O W T H$ ve $I N F$ değişkenlerine ilişkin veri setinin hem sabitli, hem de sabitli ve trendli model için durağan olduğu belirlenmiştir. Dış ticarete açıklığı temsil etmek üzere modele dâhil edilen NTOI ve RTOI değişkenleri için elde edilen sonuçlar incelendiğinde ise bu değişkenler sabitli modele göre birim kök içermekte iken, sabitli ve trendli model değişkenlerin durağan olduğunu işaret etmektedir. Maddala ve Wu (1999) birim kök testine göre hem sabitli hem de sabiti ve trendi birlikte içeren model çerçevesinde durağan olmadığı tespit edilen tek değişken $L N R G D P$ 'dir. Yatay kesit bağımlılı̆̆ını dikkate alan Pesaran (2007) (CIPS) testi sonuçları incelendiğinde ise UNEMP, GROWTH, LNRGDP ve INF değişkenlerinin durağan olduğu görülmektedir. Bu değişkenler için sıfır hipotezi, hem sabitli hem de sabitli-trendli model üzerinden elde edilen sonuçlara göre reddedilmektedir. Diş ticarete açıklık değişkenleri olan NTOI ve RTOI ise sabitli modele göre durağan iken, sabit ve trendin birlikte yer aldığı modele göre durağan değildir. İki farklı birim kök testi kullanılarak sabitli ve sabitli-trendli modeller üzerinden bu iki değişken için net bir sonuca ulaşılamadığından, bu değişkenler birinci farklarında yeniden sınamaya tabi tutulmuştur. Dış ticarete açıklık endeksindeki değişimi ifade edecek iki yeni değişken olarak da değerlendirilebilecek $\triangle N T O I$ ve $\triangle R T O I$, her iki birim kök testi ve bu birim kök testlerinin yürütüldügü alternatif modellerden elde edilen sonuçlara göre durağandır. Bu nedenle, ekonometrik analizin yürütüleceği modelde yer alan değişkenlere ilişkin veri setlerinin durağan olmasının ön koşul olduğu dinamik panel veri analizi süreci yürütülürken, dış ticarete açıklık değişkenleri modele hem düzey değerleri ile hem de sağlamlık kontrolünü de sağlamak amacıyla birinci fark ( $\triangle N T O I$ ve $\triangle R T O I$ ) değerleri ile dâhil edilmiştir.

Ekonometrik analiz yürütülürken bölgesel dış ticarete açıklık ile işsizlik arasındaki ilişki öncelikle Arellano ve Bond'un (1991) geliştirdiği Arellano-Bond, ardından Arellano ve Bover (1995) ile Blundell ve Bond'un (1998) çalışmalarına dayanan Arellano-Bover/Blundell-Bond doğrusal dinamik panel veri tahminleme yöntemleri kullanılarak araştırılmıştır. İki aşamalı Arellano-Bond doğrusal dinamik tahminleme yöntemi ile elde edilen tahmin sonuçları Tablo 5 'te verilmiştir. 
Tablo 5: İki Aşamalı Arellano-Bond Doğrusal Dinamik Tahminleme Sonuçları

\begin{tabular}{|c|c|c|c|c|}
\hline Bağımlı Değişken: UNEMP & (Model 1) & (Model 2) & (Model 3) & (Model 4) \\
\hline$U N E M P_{t-1}$ & $\begin{array}{c}0.628 * * * \\
(0.017)\end{array}$ & $\begin{array}{c}0.544 * * * \\
(0.019)\end{array}$ & $\begin{array}{c}0.670 * * * \\
(0.013)\end{array}$ & $\begin{array}{c}0.676^{* * *} \\
(0.013)\end{array}$ \\
\hline$U N E M P_{t-2}$ & $\begin{array}{c}-0.275^{* * *} \\
(0.016)\end{array}$ & $\begin{array}{c}-0.309 * * * \\
(0.017)\end{array}$ & $\begin{array}{c}-0.287 * * * \\
(0.012)\end{array}$ & $\begin{array}{c}-0.288 * * * \\
(0.012)\end{array}$ \\
\hline GROWTH & $\begin{array}{c}-0.159 * * * \\
(0.011)\end{array}$ & $\begin{array}{c}-0.143 * * * \\
(0.010)\end{array}$ & $\begin{array}{c}-0.172 * * * \\
(0.013)\end{array}$ & $\begin{array}{c}-0.169 * * * \\
(0.013)\end{array}$ \\
\hline$I N F$ & $\begin{array}{c}-0.231 * * * \\
(0.021)\end{array}$ & $\begin{array}{c}-0.284 * * * \\
(0.022)\end{array}$ & $\begin{array}{c}-0.205^{* * *} \\
(0.028)\end{array}$ & $\begin{array}{c}-0.203 * * * \\
(0.027)\end{array}$ \\
\hline NTOI & $\begin{array}{c}-0.091 * * * \\
(0.011)\end{array}$ & & & \\
\hline RTOI & & $\begin{array}{c}-0.041 * * * \\
(0.004)\end{array}$ & & \\
\hline$\triangle N T O I$ & & & $\begin{array}{c}-0.027 * * * \\
(0.009)\end{array}$ & \\
\hline$\triangle R T O I$ & & & & $\begin{array}{c}-0.023 * * * \\
(0.005)\end{array}$ \\
\hline $\mathbf{C}$ & $\begin{array}{c}10.822 * * * \\
(0.400)\end{array}$ & $\begin{array}{c}12.129 * * * \\
(0.435)\end{array}$ & $\begin{array}{c}8.628 * * * \\
(0.362) \\
\end{array}$ & $\begin{array}{c}8.629 * * * \\
(0.331) \\
\end{array}$ \\
\hline Gözlem Sayısı & 208 & 208 & 208 & 208 \\
\hline Araç Değişken Sayısı & 27 & 27 & 27 & 27 \\
\hline Wald $\chi^{2}$ & 3504.04 & 4747.05 & 20215.58 & 28680.32 \\
\hline Olasılık & 0.000 & 0.000 & 0.000 & 0.000 \\
\hline Sargan & 24.262 & 24.493 & 23.672 & 23.720 \\
\hline Olasılık & 0.280 & 0.269 & 0.309 & 0.307 \\
\hline $\mathbf{A R}(\mathbf{1})$ & -2.948 & -2.876 & -3.023 & -3.001 \\
\hline Olasılık & 0.003 & 0.004 & 0.002 & 0.003 \\
\hline $\mathbf{A R}(\mathbf{2})$ & -0.816 & -0.338 & -0.490 & -0.641 \\
\hline Olasılık & 0.415 & 0.735 & 0.624 & 0.521 \\
\hline
\end{tabular}

Tablo 5'te *: \%10, **: \%5, ***: \%1 anlam düzeyinde anlamlllı̆̆ göstermektedir. Standart hatalar parantez içinde verilmiştir.

Tablo 5'te kontrol değişkeni olarak modele ekonomik büyüme (GROWTH) değişkeninin eklendiği ve dört alternatif dış ticarete açıklık ölçütünün kullanıldığı tahmin sonuçları verilmektedir. Bu sonuçlar incelendiğinde, işsizlik oranının bir önceki dönem değeri ile pozitif, iki dönem gecikmeli değeriyle ise negatif ilişkili olduğu görülmektedir ve işsizlik oranının gecikmeli değerleri ile ilişskisi istatistiksel olarak anlamlı elde edilmiştir. Bir dönem önceki işsizlik oranında $\left(U N E M P_{t-1}\right)$ gerçekleşen 1 yüzde puanlık artış, işsizlik oranını yaklaşık 0.6 yüzde puan arttırmaktadır. İki dönem önceki işsizlik oranı $\left(U N E M P_{t-2}\right) 1$ yüzde puan arttığında ise işsizlik oranı 0.3 yüzde puan kadar azalmaktadır. Bir dönem gecikmeli değerdeki artışın işsizlik oranını arttırması şokların kalıcılığı (iş arama süresinin uzaması vb.) ile açıklanabilirken, iki dönem gecikmeli değerdeki artışın işsizlik oranını düşürmesinin bir nedeni uzayan iş arama süreleri nedeniyle ortaya çıkabilen gücenmiş işçi etkisi olabilir. Ekonomik büyüme (GROWTH) değişkeni ile işsizlik oranı (UNEMP) arasında tespit edilen anlamlı ilişkinin yönü, ekonomik teoriye dayanarak oluşturulan beklenti ile uyumlu şekilde negatiftir. İlgili dönemde ekonomik büyüme 1 yüzde puan arttı̆ğında işsizlik 0.14 ile 0.17 yüzde puan arasında bir azalış göstermektedir. Enflasyon oranı $(I N F)$ ile işsizlik oranı arasında da ters yönlü bir ilişki tespit edilmiştir. Enflasyon oranının işsizliği düşürücü etkisi, ekonomik büyüme değişkenine göre daha yüksektir. Dört alternatif dış ticarete açıklık endeksi için tahmin edilen katsayıların tamamı da negatif ve istatistiksel olarak anlamlı elde edilmiştir. Nominal dış ticarete açıklık endeksi (NTOI) ve reel dış ticarete açıklık endeksi (RTOI) için elde edilen katsayılar, bu endekslerdeki değişimi gösteren değişkenlere ( $\triangle N T O I$ ve $\triangle R T O I$ ) göre daha yüksek elde edilmiş̧tir. Ancak 
durağan değişkenler olduğu, yapılan birim kök testleri ile net olarak tespit edilebilen $\triangle N T O I$ ve $\triangle R T O I$ için elde edilen katsayılar üzerinden bir değerlendirme yapılacak olursa, bu değişkenlerdeki 1 yüzde puanlık artışın işsizlik oranını yaklaşık 0.02 yüzde puan düşürücü etkisi bulunmaktadir.

Bölgesel dış ticarete açıklık ile işsizlik arasındaki ilişkiyi araştırmak için kurulan dört alternatif modelin Wald istatistik ve bu istatistiklere ait olasılık değerleri incelendiğinde her bir modelin istatistiksel olarak anlamlı olduğu görülmüştür. Dinamik panel veri analizi sürecinde kullanılan araç değişkenlerin geçerliliğini sınamak için kullanılan ve sıfır hipotezi araç değişkenlerin geçerli olduğunu ifade eden Sargan testi sonucunda sıfır hipotezi reddedilmemiştir. Sifır hipotezi otokorelasyonun yokluğu şeklinde olan AR(1) ve AR(2) testleri ise otokorelasyon sınaması için uygulanmış ve AR(2) sonuçlarına göre hata terimleri arasında otokorelasyonun olmadığı sonucuna varılmıştır.

Sağlamlık (robustness) kontrolü yapmak amacıyla tahminleme süreci, modele GROWTH değişkeni yerine $L N R G D P$ değişkeni eklenerek tekrarlandığında Tablo 6'da sunulan sonuçlar elde edilmiştir.

Tablo 6: İki Aşamalı Arellano-Bond: Sağlamlık Kontrol Modeli

\begin{tabular}{|c|c|c|c|c|}
\hline Bağımlı Değişken: UNEMP & (Model 1) & (Model 2) & (Model 3) & (Model 4) \\
\hline$U N E M P_{t-1}$ & $\begin{array}{c}0.277 * * * \\
(0.012)\end{array}$ & $\begin{array}{c}0.259 * * * \\
(0.012)\end{array}$ & $\begin{array}{c}0.304 * * * \\
(0.011)\end{array}$ & $\begin{array}{c}0.298 * * * \\
(0.011)\end{array}$ \\
\hline$U N E M P_{t-2}$ & $\begin{array}{c}-0.396 * * * \\
(0.009)\end{array}$ & $\begin{array}{c}-0.402 * * * \\
(0.009)\end{array}$ & $\begin{array}{c}-0.391 * * * \\
(0.011)\end{array}$ & $\begin{array}{c}-0.395 * * * \\
(0.010)\end{array}$ \\
\hline$L N R G D P$ & $\begin{array}{c}-8.561 * * * \\
(0.551)\end{array}$ & $\begin{array}{c}-9.679 * * * \\
(0.735)\end{array}$ & $\begin{array}{c}-8.912 * * * \\
(0.463)\end{array}$ & $\begin{array}{c}-8.785 * * * \\
(0.481)\end{array}$ \\
\hline INF & $\begin{array}{c}-0.331 * * * \\
(0.029)\end{array}$ & $\begin{array}{c}-0.324 * * * \\
(0.029)\end{array}$ & $\begin{array}{c}-0.307 * * * \\
(0.032)\end{array}$ & $\begin{array}{c}-0.312 * * * \\
(0.031)\end{array}$ \\
\hline NTOI & $\begin{array}{c}-0.028 * * * \\
(0.010)\end{array}$ & & & \\
\hline RTOI & & $\begin{array}{c}0.007 \\
(0.006)\end{array}$ & & \\
\hline$\triangle N T O I$ & & & $\begin{array}{c}-0.046 * * * \\
(0.007)\end{array}$ & \\
\hline$\triangle R T O I$ & & & & $\begin{array}{c}-0.020 * * * \\
(0.004)\end{array}$ \\
\hline $\mathbf{C}$ & $\begin{array}{c}156.727 * * * \\
(9.319)\end{array}$ & $\begin{array}{c}174.692 * * * \\
(12.099)\end{array}$ & $\begin{array}{c}161.239 * * * \\
(7.838)\end{array}$ & $\begin{array}{c}159.332 * * * \\
(8.130)\end{array}$ \\
\hline Gözlem Sayısı & 208 & 208 & 208 & 208 \\
\hline Araç Değişken Sayısı & 27 & 27 & 27 & 27 \\
\hline Wald $\chi^{2}$ & 6039.58 & 15355.21 & 6752.88 & 6825.48 \\
\hline Olasılık & 0.000 & 0.000 & 0.000 & 0.000 \\
\hline Sargan & 23.401 & 23.439 & 22.277 & 22.508 \\
\hline Olasılık & 0.323 & 0.321 & 0.384 & 0.371 \\
\hline $\mathbf{A R}(\mathbf{1})$ & -2.458 & -2.402 & -2.532 & -2.513 \\
\hline Olasılık & 0.014 & 0.016 & 0.011 & 0.012 \\
\hline $\mathbf{A R}(2)$ & 1.151 & 1.215 & 1.179 & 1.155 \\
\hline Olasılık & 0.249 & 0.224 & 0.238 & 0.248 \\
\hline
\end{tabular}

Tablo 6'da *: \%10, **: \%5, ***: \%1 anlam düzeyinde anlamlılı̆̆ı göstermektedir. Standart hatalar parantez içinde verilmiștir.

Tablo 6'daki tahmin sonuçları incelendiğinde, bir ve iki gecikmeli dönem işsizlik oranı değerleri ile enflasyon oranı değişkenlerinin katsayıları, Tablo 5'teki sonuçlarla benzer işarete 
sahip ve istatistiksel olarak anlamlı elde edilmiştir. Bu değişkenlerin işsizlik oranını etkileme şiddetleri ise pozitif katsayıya sahip olan bir dönem gecikmeli işsizlik oranı için Tablo 5 'teki modellerde elde edilenlere göre düşük, negatif katsayıya sahip olan iki dönem gecikmeli işsizlik oranı ve enflasyon değeri için ise görece daha yüksektir. Tablo 5 'teki modellere ekonomik büyüme değişkeni yerine $L N R G D P$ dâhil edildiğinde, bu değişken için elde edilen katsayılar da negatif ve istatistiksel olarak anlamlıdır. Tablo 6'da dış ticarete açıklık değişkeni olarak RTOI'nin yer aldığı Model 2 için elde edilen katsayı istatistiksel olarak anlamsız pozitif bir ilişkiyi işaret etmiştir. Ancak diğer alternatif dış ticarete açıklık göstergeleri için yine negatif ve anlamlı bir ilişki tespit edilmiştir. Yürütülen panel birim kök testleri ile elde edilen NTOI ve RTOI değişkenlerinin durağan olmayabileceği bulgusu göz önünde bulundurulduğunda, Model 3 ve Model 4'ün sonuçlarına dayanarak bölgesel dış ticarete açılığın bölgesel işsizlik oranını azalttığı sonucuna varılabilir. Tahmin sonrası test sonuçları, sağlamlık kontrolü için oluşturulan modellerin bir bütün olarak anlamlı ve modeldeki araç değişkenlerin geçerli olduğunu, ayrıca hata terimleri arasında otokorelasyonun olmadığını göstermektedir.

Çalışmada kullanılan diğer yöntem olan iki aşamalı Arellano-Bover/Blundell-Bond doğrusal dinamik tahminleme yöntemiyle elde edilen sonuçlar Tablo 7'de sunulmaktadır.

Tablo 7: İki Aşamalı Arellano-Bover/Blundell-Bond Doğrusal Dinamik Tahminleme Sonuçları

\begin{tabular}{|c|c|c|c|c|}
\hline Bağımlı Değişken: UNEMP & (Model 1) & (Model 2) & (Model 3) & (Model 4) \\
\hline$U N E M P_{t-1}$ & $\begin{array}{c}0.748 * * * \\
(0.024)\end{array}$ & $\begin{array}{c}0.710 * * * \\
(0.023)\end{array}$ & $\begin{array}{c}0.774 * * * \\
(0.024)\end{array}$ & $\begin{array}{c}0.780 * * * \\
(0.024)\end{array}$ \\
\hline$U N E M P_{t-2}$ & $\begin{array}{c}-0.281 * * * \\
(0.014)\end{array}$ & $\begin{array}{c}-0.291 * * * \\
(0.026)\end{array}$ & $\begin{array}{c}-0.328 * * * \\
(0.021)\end{array}$ & $\begin{array}{c}-0.326 * * * \\
(0.021)\end{array}$ \\
\hline GROWTH & $\begin{array}{c}-0.166^{* * * *} \\
(0.009)\end{array}$ & $\begin{array}{c}-0.148 * * * \\
(0.009)\end{array}$ & $\begin{array}{c}-0.175^{* * *} \\
(0.009)\end{array}$ & $\begin{array}{c}-0.172 * * * \\
(0.009)\end{array}$ \\
\hline INF & $\begin{array}{c}-0.320 * * * \\
(0.028)\end{array}$ & $\begin{array}{c}-0.350 * * * \\
(0.030)\end{array}$ & $\begin{array}{c}-0.297 * * * \\
(0.039)\end{array}$ & $\begin{array}{c}-0.294 * * * \\
(0.039)\end{array}$ \\
\hline NTOI & $\begin{array}{c}-0.050 * * * \\
(0.016)\end{array}$ & & & \\
\hline RTOI & & $\begin{array}{c}-0.032 * * * \\
(0.005)\end{array}$ & & \\
\hline$\triangle N T O I$ & & & $\begin{array}{l}-0.000 \\
(0.009)\end{array}$ & \\
\hline$\triangle R T O I$ & & & & $\begin{array}{c}-0.009 * * * \\
(0.003)\end{array}$ \\
\hline $\mathbf{C}$ & $\begin{array}{c}9.717 * * * \\
(0.561)\end{array}$ & $\begin{array}{c}10.551 * * * \\
(0.526)\end{array}$ & $\begin{array}{c}8.747 * * * \\
(0.471)\end{array}$ & $\begin{array}{c}8.659 * * * \\
(0.457)\end{array}$ \\
\hline Gözlem Sayısı & 234 & 234 & 234 & 234 \\
\hline Araç Değişken Sayısı & 36 & 36 & 36 & 36 \\
\hline Wald $\chi^{2}$ & 9027.99 & 2460.06 & 5752.10 & 4845.15 \\
\hline Olasılık & 0.000 & 0.000 & 0.000 & 0.000 \\
\hline Sargan & 24.738 & 24.657 & 23.436 & 23.465 \\
\hline Olasılık & 0.738 & 0.742 & 0.797 & 0.796 \\
\hline $\mathbf{A R}(\mathbf{1})$ & -3.078 & -3.013 & -3.168 & -3.151 \\
\hline Olasılık & 0.002 & 0.003 & 0.002 & 0.002 \\
\hline $\mathbf{A R}(2)$ & -1.049 & -0.952 & -0.501 & -0.621 \\
\hline Olasılık & 0.294 & 0.341 & 0.616 & 0.535 \\
\hline
\end{tabular}

Tablo 7'de *: \%10, **: \%5, ***: \%1 düzeyinde anlamlıllğ göstermektedir. Standart hatalar parantez içinde verilmiştir. 
Tablo 7 incelendiğinde, elde edilen sonuçların Tablo 5'te iki aşamalı Arellano-Bond doğrusal dinamik tahminleme yöntemi ile ulaşılan sonuçlarla oldukça benzer olduğu görülmektedir. Tablo 7'ye göre, bir dönem gecikmeli işsizlik oranındaki 1 yüzde puanlık artış işsizlik oranını yaklaşı 0.7 yüzde puan arttırırken, iki dönem gecikmeli işsizlik oranı 1 yüzde puan arttığında işsizlik oranı yaklaşık 0.3 yüzde puan azalmaktadır. Enflasyon oranındaki artışın işsizlik oranı üzerindeki azaltıcı etkisi daha yüksek olmakla birlikte, hem enflasyon hem de büyüme oranının işsizlik oranını düşürücü etkileri tespit edilmiştir. Dört alternatif modele dâhil edilen farklı dış ticarete açıklık göstergelerinden $\triangle N T O I$ 'nin katsayısı istatistiksel olarak anlamsızdır. Diğer üç dış ticarete açıklık değişkeninin katsayıları ise bölgesel dış ticarete açıklı̆ın bölgesel işsizlik oranını azaltıcı etkisini işaret edecek şekilde istatistiksel olarak anlamlı ve negatif elde edilmiştir. Tahmin sonrası test sonuçları ise bu modellerin tahminlemede kullanılabilir modeller olduğunu göstermektedir.

Bir sonraki adımda sağlamlık kontrolü yapmak amacıyla modellere GROWTH yerine LNRGDP değişkeni eklenmiş ve dört alternatif model iki aşamalı Arellano-Bover/Blundell-Bond dinamik doğrusal tahminleme yöntemi ile tahmin edilmiştir. Elde edilen sonuçlar Tablo 8'de verilmektedir.

Tablo 8: Arellano-Bover/Blundell-Bond: Sağlamlık Kontrol Modeli

\begin{tabular}{|c|c|c|c|c|}
\hline Bağımlı Değişken: UNEMP & (Model 1) & (Model 2) & (Model 3) & (Model 4) \\
\hline$U N E M P_{t-1}$ & $\begin{array}{c}0.666 * * * \\
(0.020)\end{array}$ & $\begin{array}{c}0.646 * * * \\
(0.024)\end{array}$ & $\begin{array}{c}0.693 * * * \\
(0.019)\end{array}$ & $\begin{array}{c}0.705 * * * \\
(0.018)\end{array}$ \\
\hline$U N E M P_{t-2}$ & $\begin{array}{c}-0.350 * * * \\
(0.031)\end{array}$ & $\begin{array}{c}-0.382 * * * \\
(0.017)\end{array}$ & $\begin{array}{c}-0.405^{* * *} \\
(0.019)\end{array}$ & $\begin{array}{c}-0.388 * * * \\
(0.024)\end{array}$ \\
\hline LNRGDP & $\begin{array}{c}-1.697 * * \\
(0.668)\end{array}$ & $\begin{array}{l}-0.881 \\
(0.861)\end{array}$ & $\begin{array}{c}-2.797 * * * \\
(0.799)\end{array}$ & $\begin{array}{c}-2.713 * * * \\
(0.719)\end{array}$ \\
\hline INF & $\begin{array}{c}-0.396 * * * \\
(0.046)\end{array}$ & $\begin{array}{c}-0.440 * * * \\
(0.029)\end{array}$ & $\begin{array}{c}-0.426 * * * \\
(0.033)\end{array}$ & $\begin{array}{c}-0.401 * * * \\
(0.026)\end{array}$ \\
\hline NTOI & $\begin{array}{c}-0.083^{* * *} \\
(0.019)\end{array}$ & & & \\
\hline RTOI & & $\begin{array}{c}-0.047 * * * \\
(0.006)\end{array}$ & & \\
\hline$\triangle N T O I$ & & & $\begin{array}{c}-0.061 * * * \\
(0.013)\end{array}$ & \\
\hline$\triangle R T O I$ & & & & $\begin{array}{c}-0.041 * * * \\
(0.006)\end{array}$ \\
\hline C & $\begin{array}{c}39.852 * * * \\
(11.620)\end{array}$ & $\begin{array}{l}27.244 * \\
(14.592)\end{array}$ & $\begin{array}{c}57.215 * * * \\
(13.574)\end{array}$ & $\begin{array}{c}55.198 * * * \\
(12.185)\end{array}$ \\
\hline Gözlem Sayısı & 234 & 234 & 234 & 234 \\
\hline Araç Değişken Sayısı & 36 & 36 & 36 & 36 \\
\hline Wald $\chi^{2}$ & 5678.56 & 3533.80 & 8403.03 & 4632.37 \\
\hline Olasılık & 0.000 & 0.000 & 0.000 & 0.000 \\
\hline Sargan & 24.321 & 23.123 & 23.547 & 22.002 \\
\hline Olasılık & 0.757 & 0.810 & 0.792 & 0.854 \\
\hline $\mathbf{A R}(\mathbf{1})$ & -2.893 & -2.976 & -2.948 & -2.953 \\
\hline Olasılık & 0.004 & 0.003 & 0.003 & 0.003 \\
\hline $\mathbf{A R}(2)$ & -0.922 & -0.608 & -0.324 & -0.559 \\
\hline Olasılık & 0.357 & 0.543 & 0.746 & 0.576 \\
\hline
\end{tabular}

Tablo 8'de *: \%10, **: \%5, ***: \%1 anlam düzeyinde anlamlılı̆̆1 göstermektedir. Standart hatalar parantez içinde verilmiștir. 
Tablo 8'de verilen sonuçlar değerlendirildiğinde, alternatif modellere eklenen $L N R G D P$ değişkeninin katsayısının Model 2 için pozitif fakat istatistiksel olarak anlamsız elde edildiği görülmektedir. Bunun dışındaki tüm değişkenler için elde edilen katsayılar ise istatistiksel olarak anlamlı ve teorik beklenti ile uyumludur. Sağlamlık kontrolü yapmak amacıyla tahminlenen modellerdeki dış ticarete açıklık değişkenlerinin katsayıları da bölgesel ticari dışa açıklık ile işsizlik oranları arasında ters yönlü bir ilişki olduğunu işaret etmektedir.

Dinamik doğrusal panel veri tahminleme süreci ile genel olarak ekonomik büyüme oranı, enflasyon oranı ve ticari dışa açıklık göstergelerinin işsizlik oranını azaltıcı etkileri tespit edildikten sonra, bu değişkenlerle işsizlik oranı arasındaki ilişkinin çift yönlü olup olmadığını sınamak amacıyla Dumitrescu ve Hurlin (2012) panel nedensellik testi uygulanmıştır. Dumitrescu ve Hurlin (2012) panel nedensellik test sonuçları Tablo 9'da sunulmaktadır.

Tablo 9: Dumitrescu-Hurlin Panel Nedensellik Testi

\begin{tabular}{lccc}
\hline & $\bar{W}$ İstatistiği & $\bar{z}$ İstatistiği & Olasılık \\
\hline GROWT H, UNEMP'in Granger nedeni değildir. & 2.1983 & 4.3206 & 0.0000 \\
UNEMP, GROWTH'un Granger nedeni değildir. & 1.3314 & 1.3314 & 0.2322 \\
LNRGDP, UNEMP'in Granger nedeni değildir. & 1.6499 & 2.3432 & 0.0191 \\
UNEMP, LNRGDP'nin Granger nedeni değildir. & 1.5119 & 1.8457 & 0.0649 \\
INF, UNEMP'in Granger nedeni değildir. & 2.1735 & 4.2311 & 0.0000 \\
UNEMP, INF'in Granger nedeni değildir. & 1.7091 & 2.5568 & 0.0106 \\
NTOI, UNEMP'in Granger nedeni değildir. & 2.2857 & 4.6358 & 0.0000 \\
UNEMP, NTOI'nin Granger nedeni değildir. & 2.6467 & 5.9372 & 0.0000 \\
RTOI, UNEMP'in Granger nedeni değildir. & 2.1783 & 4.2485 & 0.0000 \\
UNEMP, RTOI'nin Granger nedeni değildir. & 1.7204 & 2.5975 & 0.0094 \\
\hline
\end{tabular}

Tablo 9'da verilen Dumitrescu-Hurlin panel nedensellik testinin $\bar{z}$ istatistiği ve bu istatistiğe ait olasılık değerleri incelendiğinde, ekonomik büyümenin (GROWTH) işsizlik oranının (UNEMP) Granger anlamda nedeni olduğu görülmektedir; ancak bunun tersi doğru değildir. Diğer bir deyişle, test sonuçları ekonomik büyümeden işsizlik oranına doğru tek yönlü bir nedensel ilişkiyi işaret etmektedir. Ancak logaritmik formdaki reel GSYH ile işsizlik oranı arasındaki ilişkinin \%10 anlam düzeyinde karşılıklı olduğu söylenebilir. Enflasyon oranı (INF) ile işsizlik oranı (UNEMP) arasında ise Phillips eğrisi ile ifade edildiği şekilde bir değiş tokuş söz konusudur. Yani bu iki değişken arasında karşılıklı bir nedensel ilişki bulunmaktadır. Ticari dışa açıklık değişkenleri olan NTOI ve RTOI ile işsizlik oranı arasındaki nedensellik ilişkisi de karşılıklıdır. Daha açık bir ifade ile ticari dışa açıklık işsizlik oranının Granger nedeni iken, işsizlik oranı da ticari açıklığı etkileyen bir faktör olarak belirlenmiştir.

\section{SONUÇ}

Bölgesel gelişmişlik düzeyleri incelenirken genellikle odaklanılan ilk gösterge kişi başına bölgesel gelir olmakla birlikte, günümüzde bölgesel sosyo-ekonomik gelişmişlik farklılıklarının azaltılmasına yönelik politikaların geliştirilmesine daha fazla önem verilmektedir. $\mathrm{Bu}$ nedenle, bölgesel düzeyde pek çok sosyo-ekonomik göstergeye ilişkin veri toplanmakta ve bu veriler daha etkin bölgesel politikaların uygulanabilmesi amaciyla değerlendirilmeye alınmaktadır. Avrupa Birliği bölgesel düzeydeki verilerin elde edilebilmesi amacıyla The Nomenclature of Territorial Units for Statistics (NUTS) çerçevesinde bölgesel istatistiki birimler tanımlamıştır. Türkiye de Avrupa Birliğine uyum çalışmaları çerçevesinde bölgesel politikalara hız vermek için İstatistiki Bölge Birimleri Sınıflamasını (IBBS) oluşturmuştur. Bu sınıflamaya 
göre Türkiye'nin ikinci düzey bölge olarak belirlemiş olduğu 26 istatistiki bölge birimi bulunmaktadır.

Bölgesel sosyo-ekonomik gelişmişlik düzeyleri kapsamlı bir şekilde değerlendirilirken dikkate alınan göstergelerin bir kısmı emek piyasasına ilişkindir. Ekonomik teori ile de ortaya konulan çalı̧̧ma düzeyi ile üretim ve dolayısıyla gelir düzeyi arasındaki sıkı ilişki göz önünde bulundurulduğunda, bölgesel sosyo-ekonomik gelişmişlik düzeyi farklılıklarının oluşumunda bölgesel işsizlik oranı farklılıklarının önemli bir etkisi söz konusu olmaktadır. Bu çerçevede, T.C. Kalkınma Bakanlığı'nın (2013) bölgesel sosyo-ekonomik gelişmişlik endeksi hesaplamalarında da bölgesel işsizlik oranları emek piyasası göstergeleri arasında yer almaktadır.

İşsizlikle mücadele politikalarının odağında genellikle yeni iş imkânlarının oluşturulması bulunmaktadır. $\mathrm{Bu}$ ise ancak yeni üretken yatırımların yapılmasına bağlıdır. Bununla birlikte işsizliği azaltma yönündeki politikalar bölgesel farklılıkların ortadan kaldırılması amacı ile birleştirildiğinde, yalnızca yeni yatırımların yapılmasını ve bu yatırımların görece geri kalmış bölgelere yönlendirilmesini sağlamak yetmeyebilir. Çünkü yeni işletmelerin yalnızca bölge piyasasına yönelik üretim yapması ve bölgesel talebin de üretim artışı sağlayamayacak ölçüde düşük kalması durumunda, istihdamda yeterli artış gerçekleşmeyebilecek, bu ise işsizlik sorununun bölgesel düzeyde kalıcı olmasına neden olabilecektir. Diğer taraftan, mevcut ve yeni işletmeler dış piyasalara yönlendirildiğinde, ihracatın sunduğu daha geniş piyasa imkânı ile bu işletmelerin üretim düzeylerini arttırıcı bir etki sağlanabilecektir. Dolayısıyla bölge işletmelerinin izlenen politikalarla diş ticarete açık hale getirilmesi, bölgesel işsizlikle mücadelede etkili bir araç olma potansiyeline sahiptir.

Bu çalışmada, Türkiye'de bölgesel ticari dışa açıklığın işsizlik oranını azaltıcı bir etkisi olup olmadığının araştırılması amaçlanmıştır. Bu amaçla, Türkiye'de İBBS'ye göre belirlenen 2 . düzey bölgelerinin (26 bölge) 2004-2014 dönemi verileriyle oluşturulan panel veri seti dinamik doğrusal panel veri tahminleme yöntemleri ve Dumitrescu-Hurlin panel nedensellik testi ile analiz edilmiştir. Bölgesel ticari dişa açıklığın bölgesel işsizlik oranı üzerindeki etkisini belirlemek üzere oluşturulan modele ekonomik büyüme, reel GSYH ve enflasyon oranı gibi kontrol değişkenleri eklenmiştir. Ekonometrik analiz süreci, dışa açıklık ölçütü olarak nominal ve reel dışa açıklık endeksleri ile bu endekslerin birinci derece farklarının kullanıldığ 1 dört alternatif model üzerinden yürütülmüştür. Kontrol modelleri ile de sağlamlık sinaması yapılan dinamik doğrusal panel veri analiz sonuçlarına göre, bölgesel dış ticarete açıklığın bölgesel işsizlik oranını düşürücü anlamlı bir etkisi bulunmaktadır. Dumitrescu-Hurlin panel nedensellik testi sonuçları ise bölgesel diş ticarete açıklık ile bölgesel işsizlik oranı arasında çift yönlü bir ilişki olduğunu göstermiştir.

Çalışmada ulaşılan bulgular, Türkiye'de bölgelerin ticari dışa açıklık düzeylerinin arttırılmasının bölgesel işsizlikle mücadelede etkili bir politika olarak kullanılabileceğini işaret etmektedir. Bu politikaların görece geri kalmış bölgeler desteklenecek şekilde uygulanması ise aynı zamanda bölgesel gelişmiş farklılıklarının azaltılmasına yardımcı olabilecektir. Türkiye için oluşturulan İBBS, bölgelerdeki işletmelere verilecek kalkınma teşvikleri açısından da bir çerçeve oluşturmaktadır. Buradan hareketle, bölgelerdeki işletmelere verilecek kalkınma teşviklerinin, işletmelerin dış ticarete yönelik faaliyette bulunmalarını da destekler nitelikte oluşturulmasının son derece önemli olduğu söylenebilir. 


\section{KAYNAKÇA}

Alcalá, F., \& Ciccone, A. (2004). Trade and productivity. The Quarterly Journal of Economics, 119(2), 613-646. DOI: $10.1162 / 0033553041382139$

Arellano, M., \& Bond, S. (1991). Some tests of specification for panel data: Monte Carlo evidence and an application to employment equations. Review of Economic Studies, 58(2), 277-297. DOI: 10.2307/2297968

Arellano, M., \& Bover, O. (1995). Another look at the instrumental variable estimation of error-components models. Journal of Econometrics, 68(1), 9-51. DOI: 10.1016/0304-4076(94)01642-D

Ayaş, N. ve Çeștepe, H. (2010). Dış ticaretin istihdam üzerindeki etkileri: Türk imalat sanayi örneği. Süleyman Demirel Üniversitesi Iktisadi ve İdari Bilimler Fakültesi Dergisi, 15(2), 259-281. Retrieved from http://dergipark.gov.tr/sduiibfd/issue/20827/223030

Blundell, R., \& Bond, S. (1998). Initial conditions and moment restrictions in dynamic panel data models. Journal of Econometrics, 87(1), 115-143.

Brecher, R. A. (1974). Minimum wage rates and the pure theory of international trade. The Quarterly Journal of Economics, 88(1), 98-116. DOI: 10.2307/1881796

Davidson, C., Martin, L., \& Matusz, S. (1999). Trade and search generated unemployment. Journal of International Economics, 48(2), 271-299. DOI: 10.1016/S0022-1996(98)00040-3

Davis, D. R. (1998). Does European unemployment prop up American wages? National labor markets and global trade. The American Economic Review, 88(3), 478-494. Retrieved from https://www.jstor.org/stable/116845

De Pinto, M. (2013). International trade and unemployment: On the redistribution of trade gains when firms matter. Berlin: Springer-Verlag.

Dumitrescu, E. I., \& Hurlin, C. (2012). Testing for Granger non-causality in heterogeneous panels. Economic Modelling, 29(4), 1450-1460. DOI: 10.1016/j.econmod.2012.02.014

Dutt, P., Mitra, D., \& Ranjan, P. (2008). International trade and unemployment: Theory and cross-national evidence. $\begin{array}{llllll}\text { Economics Faculty } & \text { Scholarship, } & 68, & \text { ss. } & 1-36 . & \text { Retrieved }\end{array}$ https://surface.syr.edu/cgi/viewcontent.cgi?article=1093\&context=ecn

Elhorst, J. P. (2003). The mystery of regional unemployment differentials: Theoretical and empirical explanations. Journal of Economic Surveys, 17(5), 709-748. DOI: 10.1046/j.1467-6419.2003.00211.x

Erlat, G. (2000). Measuring the impact of trade flows on employment in the Turkish manufacturing industry. Applied Economics, 32(9), 1169-1180. DOI: 10.1080/000368400404317

Felbermayr, G., Prat, J., \& Schmerer, H. J. (2008). Globalization and labor market outcomes: Wage bargaining, search frictions and firm heterogeneity. IZA Discussion Paper Series, 3363, 1-51.

Felbermayr, G., Prat, J., \& Schmerer, H. J. (2009). Trade and unemployment: What do the data say? IZA Discussion Paper Series, 4184, 1-47. Retrieved from http://ftp.iza.org/dp3363.pdf

Fu, X., \& Balasubramanyam, V. N. (2005). Exports, foreign direct investment and employment: The case of China. The World Economy, 28(4), 607-625. DOI: 10.1111/j.1467-9701.2005.00694.x

Fugazza, M., Carrère, C., Olarreaga, M., \& Robert-Nicoud, F. (2014). Policy issues in international trade and commodities research study series: No. 64. Trade in employment. New York and Geneva: United Nations Conference on Trade and Development. Retrieved from https://unctad.org/en/PublicationsLibrary/itcdtab64_en.pdf

Gozgor, G. (2014). The impact of trade openness on the unemployment rate in G7 countries. The Journal of International Trade \& Economic Development, 23(7), 1018-1037. DOI: 10.1080/09638199.2013.827233

Gozgor, G. ve Piskin, A. (2011). İşsizlik ve diş ticaret: Türkiye'deki bölgeler için genelleştirilmiş momentler yöntemidinamik panel veri yaklaşımı. Business and Economics Research Journal, 2(3), 121-138. Retrieved from https://www.berjournal.com/tr/issizlik-ve-dis-ticaret-turkiye'deki-bolgeler-icin-genellestirilmis-momentler-yontemidinamik-panel-veri-yaklasimi

Gül, E. ve Kamac1, A. (2012). Dış ticaretin istihdam üzerindeki etkileri: Bir panel veri analizi. Anadolu Üniversitesi Sosyal Bilimler Dergisi, 12(4), 23-32. Retrieved from https://earsiv.anadolu.edu.tr/xmlui/handle/11421/131

Helpman, E., Itskhoki, O., \& Redding, S. (2011). Trade and labor market outcomes. NBER Working Paper Series, 16662, 1-47. Retrieved from https://www.nber.org/papers/w16662.pdf 
Kamei, K. (2014). International trade, unemployment, and firm owners in a general equilibrium with oligopoly. Munich Personal RePEc Archive, 59388, 1-15. Retrieved from https://mpra.ub.unimuenchen.de/59388/1/MPRA_paper_59388.pdf

Kılıç, E. ve Kutlu, E. (2017). Trade openness and unemployment in transition economies: A dynamic heterogeneous panel data analysis. In F. Yenilmez \& E. K1lıc (Eds.), Handbook of Research on Unemployment and Labor Market Sustainability in the Era Of Globalization (pp. 371-387). Hershey, PA: IGI Global. DOI: 10.4018/978-1-5225-20085.ch020

Maddala, G. S., \& Wu, S. (1999). A comparative study of unit root tests with panel data and a new simple test. Oxford Bulletin of Economics and statistics, 61(S1), 631-652. DOI: 10.1111/1468-0084.0610s1631

Melitz, M. J. (2003). The impact of trade on intra-industry reallocations and aggregate industry productivity. Econometrica, 71(6), 1695-1725. Retrieved from https://www.jstor.org/stable/1555536

Moore, M. P., \& Ranjan, P. (2005). Globalisation vs. skill-biased technological change: Implications for unemployment and wage inequality. The Economic Journal, 115(503), 391-422. DOI: 10.1111/j.14680297.2005.00994.x

Neary, J. P. (2009, February) International trade in general oligopolistic equilibrium. Paper presented at the meeting of CESifo Area Conference on Global Economy, Munich. Retrieved from https://www.cesifogroup.de/dms/ifodoc/docs/Akad_Conf/CFP_CONF/CFP_CONF_2009/Conf-ge09-Whalley/Conf-ge09papers/ge09_neary_9107667_en.pdf

Nicita, A. (2006). Export led growth, pro-poor or not? Evidence from Madagascar's textile and apparel industry. World Bank Policy Research Working Paper, 3841, 1-25. Retrieved from http://documents.worldbank.org/curated/en/438991468055157604/pdf/wps3841.pdf

Özel, H. A., Topkaya, Ö. ve Kurt, S. (2012). Ticari açıklık ve işsizlik ilişkisi: Türkiye örneği. Kamu-İs, İş Hukuku ve İtisat Dergisi, 12(4), 29-54. Retrieved from http://www.kamu-is.org.tr/pdf/1242.pdf

Papageorgiou, D., Choksi, A. M., \& Michaely, M. (1990). Liberalizing foreign trade in developing countries: The lessons of experience. Washington, DC: World Bank. Retrieved from http://documents.worldbank.org/curated/en/824261468765268505/pdf/multi-page.pdf

Pesaran, M. H. (2004). General diagnostic tests for cross section dependence in panels. IZA Discussion Paper, 1240, 1-42. Retrieved from http://ftp.iza.org/dp1240.pdf

Pesaran, M. H. (2007). A simple panel unit root test in the presence of cross-section dependence. Journal of Applied Econometrics, 22(2), 265-312. DOI: 10.1002/jae.951

Polat, Ö. ve Uslu, E. E. (2010). Türkiye imalat sanayinde dış ticaretin istihdam üzerindeki etkisi. Gaziantep Üniversitesi Sosyal Bilimler Dergisi, 9(3), 489-504. Retrieved from http://dergipark.gov.tr/download/articlefile/223444

Polat, O., Uslu, E. E. ve Aydemir, C. (2011). İmalat sanayinde dış ticaret ve istihdamın panel veri analizi. Business and Economics Research Journal, 2(3), 161-171. Retrieved from http://www.berjournal.com/wpcontent/plugins/downloads-manager/upload/BERJ\%202(3)11\%20Article\%2010\%20pp.161-171.pdf

Rama, M. (2003). Globalization and workers in developing countries. World Bank Policy Research Working Paper, 2958, 1-38. Retrieved from http://documents.worldbank.org/curated/en/846921467988877048/pdf/multiOpage.pdf

Sandalcılar, A. R. ve Yalman, İ. N. (2012). Türkiye'de dış ticaretteki serbestleşmenin işgücü piyasaları üzerindeki etkileri. Eskişehir Osmangazi Üniversitesi İktisadi ve İdari Bilimler Dergisi, 7(2), 49-65. Retrieved from http://dergipark.gov.tr/download/article-file/65451

Seyidoğlu, H. (2009). Uluslararası iktisat: Teori politika ve uygulama. İstanbul: Güzem Can Yayınları.

Shapiro, C., \& Stiglitz, J. (1984). Equilibrium unemployment as a worker discipline device. American Economic Review, 74(2), 433-444. Retrieved from https://www.jstor.org/stable/1804018

T.C. Kalkınma Bakanlığı, (2013). Illlerin ve bölgelerin sosyo-ekonomik gelişmişlik sıralaması araştırması SEGE 2011. Ankara: Bölgesel Gelișme ve Yapısal Uyum Genel Müdürlüğü Yayını. Retrieved from http://www3.kalkinma.gov.tr/DocObjects/View/15310/SEGE-2011.pdf

Y1lmaz, A. ve Altay, H. (2016, July). The cointegration relationship between trade openness and unemployment rate: A panel data analysis for G-8 countries. In EUREFE'16 bildiri kitabı (Vol. 2, pp. 823-844). Retrieved March 18, 2017, from http://eurefe.org/eurefecilt-2.pdf 